\title{
Electro-gene therapy followed by intratumoral injection of pCDNA3.1-p27kip1 wild type in human tongue base cancer cells sp-c3 xenograft
}

\author{
Supriatno*, Inne Suherna Sasmita** \\ *Department of Oral Medicine Faculty of Dentistry Universitas Gadjah Mada \\ "Department of Pediatric Dentistry Faculty of Dentistry Universitas Padjadjaran
}

\section{ABSTRACT}

Human tongue base cancers are characterized by a high degree of local invasion and metastasis to the regional lymph nodes and included a disease with difficult treatment. A novel method for highefficiency and region-controlled in vivo gene transfer was developed by combining electro-gene therapy and plasmid (pcDNA). The aims of the study were to examine the efficiency of transfection of $p 27^{\text {kip } 1}$ gene by electro-gene therapy, and to evaluate $p 27^{\text {kip1 }}$ gene therapy in Supri's clone-3 (SP-C3) xenografts using pcDNA3.1-p27 ${ }^{\text {kip1 }}$ wild type (wt) and pcDNA3.1 empty vector (neo) with electro-gene therapy. To investigate gene transfer method, the enhanced green fluorescence protein (EGFP) gene was transfected into xenografts by electro-gene therapy. The efficiency of $p 27^{\text {kip } 1}$ gene transfection at protein level was confirmed by Western blotting. To estimate the reduction of tumor size in Wistar Balb/c mice after electro-gene therapy with $\mathrm{p} 27^{\mathrm{kip} 1}$ wt gene was examined by tumorigenesis assay. To evaluate the induction of apoptosis was carried out by colorimetric assay. Result, the growth of tumors was markedly suppressed by $\mathrm{p} 27^{\text {Kip } 1}$ wt gene transfection. Up-regulation of p27 ${ }^{\text {Kip } 1}$ protein was detected in pcDNA3.1-p27 ${ }^{\text {kip } 1}$ wt. Apoptosis induction through activity of caspase -3 and -9 were significantly increased in p27 ${ }^{\text {kip } 1}$ wttransfected tumors. These results suggest that it is possible to transfer p27 $7^{\text {Kip } 1}$ wt into tongue base cancer cell xenografts using electro-gene therapy. $\mathrm{p} 27^{\mathrm{kip} 1} \mathrm{wt}$ had a high-potencially to suppress the growth of tumors. Conclusion, electro-gene therapy followed by intratumoral injection of pcDNA3.1-p27 ${ }^{\text {Kip } 1} \mathrm{wt}$ had a high-potencially to suppress the growth of a human tongue base cancer cell xenograft.

Key words: pcDNA3.1-p27 ${ }^{\text {kip1 }}$ wt, electro-gene therapy, tongue base cancer SP-C3, xenograft

\section{INTRODUCTION}

Electro-gene therapy or electroporation or electric pulse has been developed for the purpose of achieving highly efficient in vitro gene or drug transfer. ${ }^{1,2}$ This system provides markedly higher efficiency transfer compared with other non-viral transfer system, including cationic liposome. ${ }^{3}$
Electro-gene therapy has been applied to in vivo drug transfer for cancer treatment and clinical trial has been started. ${ }^{4}$ Electro-gene therapy has become more and more popular as an effective technique for introduction of foreign DNA into cells of various kinds of mammalian cells. ${ }^{5,6}$ for investigation of gene regulation ${ }^{7}$, and has been demonstrated to be highly useful in transfecting

Correspondence author: Supriatno, Department of Oral Medicine, Faculty of Dentistry, Universitas Gadjah Mada, Jln. Denta No. 1 Sekip Utara, Yogyakarta 55281, Indonesia, Tel.IFax: 0274-515307, E-mail: pridentagama_oncolog@yahoo.com. 
human hematopoetic stem cells for gene therapy. ${ }^{8}$ However, the transfection efficiency in mammalian cells using in vivo electro-gene therapy has received little attention ${ }^{9}$ and usually is still low, typically about $0.01-1 \% .^{10}$ Because electro-gene therapy is a physical method, it has a little biological side effect and is free of chemical toxicity. ${ }^{7}$

Many types of methods and techniques for in vivo gene transfer have been developed, and some of them have already been applied in clinical trials. ${ }^{1}$ Non-viral gene transfer, "naked" plasmid DNA is an ideal system for gene transfer. A plasmid mediated method would be economical and easy because use of this system obviates the necessity to construct viral vectors, establish clones of producer cells, access viral titers and presence of replication-competent helper virus, which has been known to activate passive oncogenes. The transfer procedure could be easily repeated because "naked" plasmid DNA has little antigenicity to the host body. ${ }^{11}$

Human tongue base cancers are characterized by a high degree of local invasion and a high rate of metastases to the cervical lymph nodes. Moreover, human tongue base cancer frequently shows local recurrence after initial treatment, probably due to micro invasion and/or metastasis of tumor cells at the primary site. ${ }^{12}$ SP-C3 cell line has an extremely growth, highly invasion and metastasis to the regional and distant lymph nodes, rapidly local recurrence after radical excision, highly mortality, and included a disease with difficult treatment. ${ }^{13}$ Despite advanced in surgery, radiotherapy and chemotherapy, the survival of patients with oral tongue cancer has not significantly improved over the past several decades. Also, treatment options for recurrent or refractory oral cancers are limited. ${ }^{14}$ Furthermore, the ratio of mortality or incidence in 1980 and 1990 was 0.48 and 0.47 , respectively ${ }^{15}$ and the prognosis has not changed during the past 10 years. However, as a new strategy for refractory cancer, gene therapy is watched with keen interest.

$\mathrm{p} 27^{\mathrm{kip} 1}$ is a universal cyclin-dependent kinase inhibitor that directly inhibits the enzymatic activity of cyclin-CDK complexes, resulting in cell cycle arrest at $\mathrm{G}_{1} \cdot{ }^{16} \mathrm{p} 27^{\mathrm{kip} 1}$ has an important prognostic factor in various malignancies. Recently, decreased expression of p27 $7^{\text {kip } 1}$ has been frequently detected in human cancer. ${ }^{17-19}$ In addition, loss of $\mathrm{p} 27^{\mathrm{kip} 1}$ has been associated with disease progression and an unfavorable outcome in several malignancies. ${ }^{20}$ Furthermore, mice lacking the p27 $7^{\text {kip } 1}$ gene show an increase in body weight, thymic hypertrophy and hyperplasia of pituitary intermediate lobe adrenocorticotropic hormon cells, adrenal glands and gonadal organ. ${ }^{21}$ Moreover, malignant human oral cancer cells transfection with $\mathrm{p} 27^{\mathrm{kip} 1}$ gene leads to inhibition of proliferation, invasion and metastasis. ${ }^{22,23}$

In the present study, the efficiency of transfection of exogenous $p 27^{\text {kip } 1}$ gene by electrogene therapy, and the antitumor activity of $\mathrm{p} 27^{\mathrm{Kip}}$ gene therapy in human tongue base cancer cells Supri's clone-3 (SP-C3) xenografts using pcDNA3.1. p27 $7^{\text {kip } 1}$ wild type (wt) and pcDNA3.1 empty vector (neo) with the local application of electric pulses was evaluated.

\section{MATERIALS AND METHODS}

Cell and cell culture. SP-C3 cells were isolated from a cervical lymph-node metastasis of a human tongue base cancer patient. ${ }^{22}$ The original tumor SP-C3 cells were moderately differentiated from human tongue base cancer. Cells were maintained in Dulbecco's modified eagle medium (DMEM, Sigma, St. Louis, MO, USA) supplemented with $10 \%$ fetal calf serum (FCS, Moregate BioTech, Bulimba, Australia), $100 \mu \mathrm{g} / \mathrm{ml}$ streptomycin, and 100 units/ml penicillin (Invitrogen Corp, Carlsbad, CA, USA).

Construction of a mammalian expression vector. The mammalian expression vectors $\mathrm{pcD}$ NA3.1-p27 ${ }^{\text {kip } 1}$ wt (Invitrogen) containing sense oriented human wild type p27 $7^{\text {kip } 1}$ cDNA was constructed. Briefly, pcDNA3.1 (+) was digested with Kpn1 (Takara Biomedicals, Kusatsu, Japan) and BamH1 (Takara), and dephosphorylated by calf intestinal alkaline phosphate (Roche Diagnostics, Mannheim, Germany). The human wild type p27 $7^{\text {kip } 1}$ CDNA fragment (0.69 kb Kpn1 and BamH1 fragment) was obtained as a generous gift from Dr. J. Massague (Howard Hughes Medical Institute, Memorial Sloan-Kettering Cancer Center, NY). This fragment containing the human wild type $\mathrm{p} 27^{\text {kip } 1}$ open reading frame was ligated to the prepared cloning site of pcDNA3.1 (+) by T4 DNA ligase (Takara). The direction of the ligated fragmen was confirmed by sequencing analysis with a spesific primer ( $\mathrm{p} 27^{\mathrm{kip} 1 .}$ 
SQP: 5'-ATGTCAAACGTGGCGAGTGTC-3') for human $p 27^{\text {kip } 1}$ CDNA The DNA. sequence was determined by the dideoxy chain termination method, using fluorescene-labeled primers and a Thermo Sequenase Cycle sequencing kit (Amersham Pharmacia Biotech, Sweden). Electrophoresis and scanning were performed with a Shimadzu DSQ500 DNA sequencer (Shimadzu, Kyoto, Japan).

In vivo tumorigenesis and electrotransfection. The human tongue base cancer cell line, SP-C3 cells were trypsinized, washed with PBS, and suspended in saline solution at $1 \times 10^{6}$ cells in $0.1 \mathrm{ml}$. Cell suspension $(0.1 \mathrm{ml})$ was injected into each male nude mouse with Balb/cA Jclnu genetic background (Clea Japan, Inc. Tokyo, Japan) subcutan in the flank area. A pair of $1 \mathrm{~cm}$ diameter of disc-shaped electrodes (pinsettes-type electrode 449-10 PRG, Meiwa Shoji, Tokyo, Japan) was used to nip the tumor nodule through the skin. A series of eight electrical pulses with pulse length of $1 \mathrm{msec}$ was delivered with a standard square wave electroporator BTX T820 (BTX, Inc, San Diego, CA). The voltage of $80 \mathrm{~V} / 1.0 \mathrm{~cm}$ diameters of xenografts was used. Then, it delivered an appropriate pulse length and frequency of pulses according to previous report. ${ }^{24,25}$ Immediately after electrical pulsing, $20 \mu \mathrm{g}$ of pcDNA-neo or pCDNA3.1-p27 ${ }^{\text {Kip } 1}$ wt dissolved in $50 \mu \mathrm{l}$ of Tris EDTA buffer was directly injected into the tumor nodule. This electroporation and injection were performed a total of three times at 3-day intervals. Tumor volume and body weight were measured every 3 days from the time electroporation started until the mice were sacrificed. The tumor volume was determined by measuring length $(L)$ and width (W) diameters of the tumor and calculated as $V=0.4$ $x \mathrm{LxW} \mathrm{W}^{2}{ }^{13}$

Detection of reporter gene expression in vivo. For fluorescence microscopy, PEGFP-C3 vector (BD Bioscience Clontech) -injected tumors for $48 \mathrm{~h}$ were sectioned and mounted in PBS for immediate microscopy. To visualize EGFP, a Xenon arch lamp and a FITC filter were used on a Zeiss Axioskop. Images were acquired with a color CCD camera and frame-grabbing equipment at identical magnification, light intensity and amplification for each sample. ${ }^{13}$

Western blotting analysis. Cell lysates were prepared from the xenograft tumor tissue. Briefly, samples containing equal amounts of protein (50 $\mu g)$ were electrophoresed on a SDS-polyacrylamide gel and transferred to a nitrocellulose filter (PVDF membrane: BioRad, Hercules, CA, USA). The filters were blocked in TBS containing $5 \%$ nonfat milk powder at $37^{\circ} \mathrm{C}$ for 1 hour and then incubated with a 1: 1000 dilution of the monoclonal antibody against p27 protein (clone 1B4, monoclonal antibody, Novocastra Laboratories, New Castle, UK) and an Amersham ECL kit (Amersham Pharmacia Biotech) as the primary antibody. Mouse antibody IgM was used as the secondary antibody (1:2000). Anti-a tubulin monoclonal antibody (Zymed laboratories, San Fransisco, CA, USA) was used for normalization of Western blot analysis.

Detection of apoptosis using colorimetric assay. Induction of apoptosis was measured using the colorimetric assay kit (caspase- 3 and caspase9; BioVision Research Product, CA, USA) according to the manufacturer's directions. Briefly, equal amounts of tissue extracts prepared from SP-C3 transfected with pcDNA3.1-p27 ${ }^{\text {Kip1 }}$ wtor pcDNA3.1. neo were incubated with the substrate (Ac-DVEDpNA or Ac-LEHD-pNA) in the assay buffer for 2 hours at $37^{\circ} \mathrm{C}$. Absorbance was measured at 405 $\mathrm{nm}$ using a microplate reader (BioRad, USA). Each determination was performed in triplicate.

Statistical analysis. Statistical analysis was performed with a Stat Work program for Macintosh computers (Cricket Software, Philadelphia, PA, USA). Data were analyzed for statistical significance of $95 \%$ with two-way ANOVA and Student's t-test.

\section{RESULTS}

Detection of transgene expression in Xenograft. Expression of reporter gene (EGFP) after plasmid injection and electro-gene therapy in tumor tissue was assessed in fresh tissue sections by light microscopy fluorescence imaging. Very few cells were positive when only naked DNA without consecutive electroporation was injected. The combination with electroporation resulted in consistenly efficient transduction of a higher number of cells with EGFP reporter gene ( $P$ $=0.001)$ (Fig. 1).

In vivo effect of $\mathrm{p} 27^{\mathrm{kip} 1}$ wt transfection by electroporation on tumor growth. The mean relative volume for SP-C3 xenografts treated with an injection of pcDNA3.1-p27 $7^{\text {kip } 1}$ wt or pcDNA3.1 empty vector was shown in Fig. 2A, p27 $7^{\text {kip } 1-u p-~}$ 


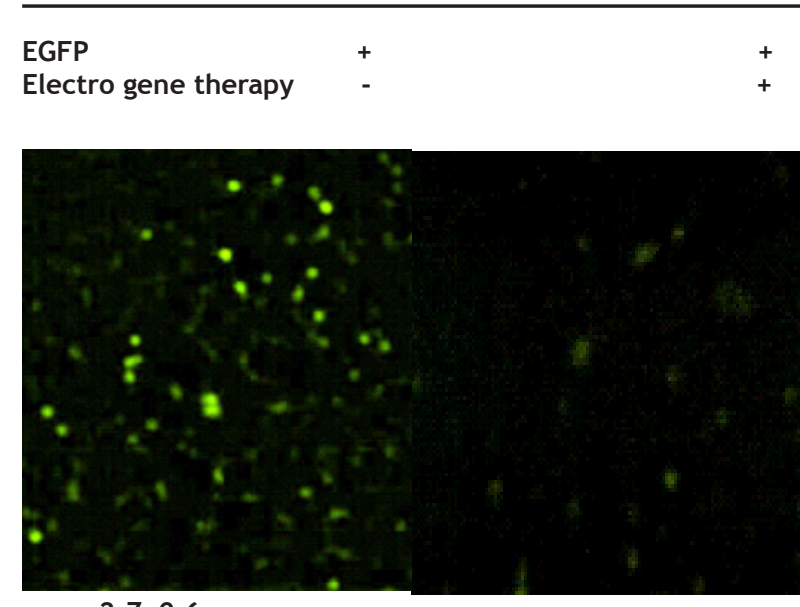

$2.7+0.6$

$70.6+2.7$

Figure 1. Detection of reporter gene expresion.
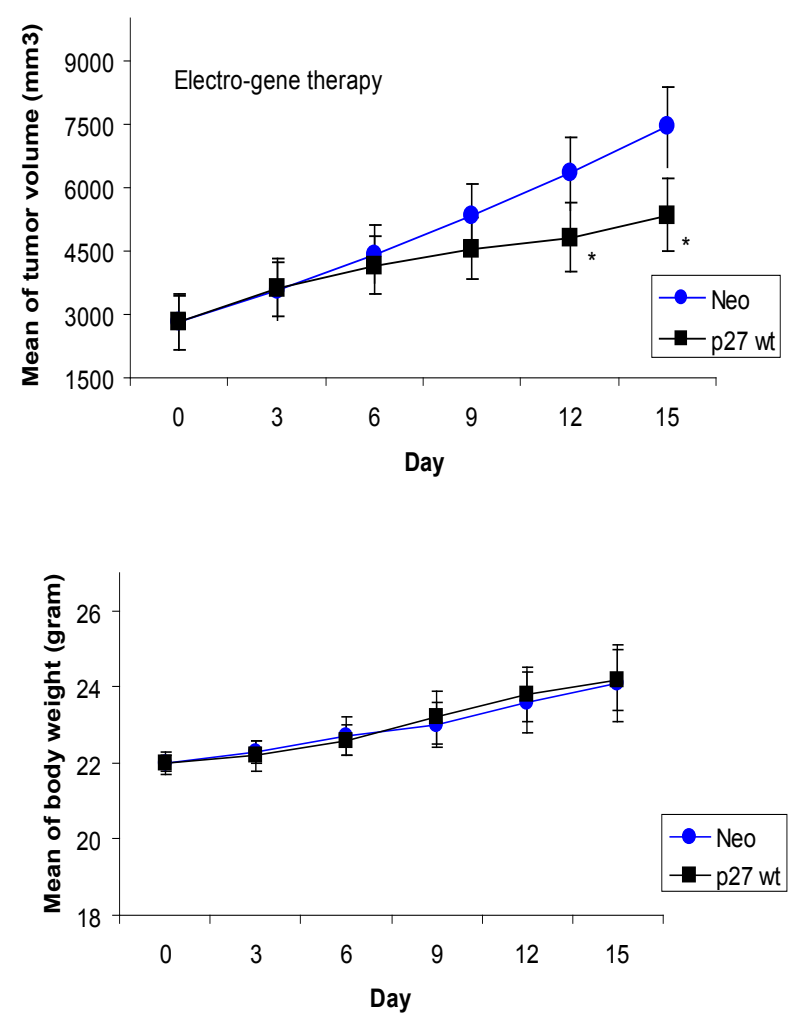

Figure 2. A. Growth of tumor formed by transfectants, B. Change of body weight in mice. ${ }^{*} P<0.05$.

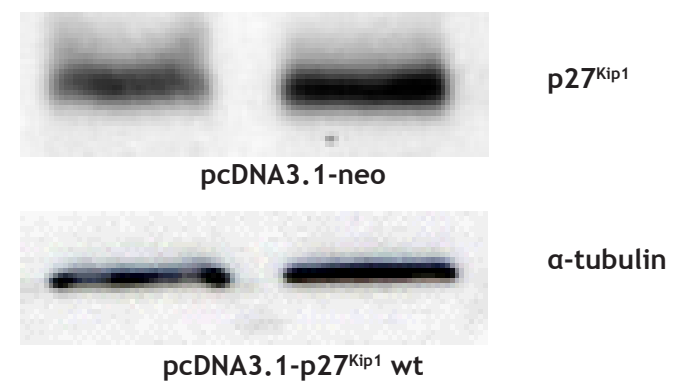

Figure 3. Expression of $p 27^{\text {Kip } 1}$ and a-tubulin protein in the pcDNA3.1-neo and pcDNA3.1-p27 ${ }^{\text {Kip1 }}$ wt transfectant tissues. regulated tumors (pcDNA3.1-p27 $7^{\text {kip1 }}$ wt-injected) became much smaller than pcDNA3.1 empty vector-injected tumors $(P=0.001)$. Interestingly, during the experimental period, no loss of body weight was observed in each treatment group, and that no skin region including a burn also was observed (Fig. 2B).

Expression of $\mathrm{p} 27^{\mathrm{kip} 1}$ protein in xenografts. To evaluate the efficiency of transfection of p27 ${ }^{\text {Kip } 1}$ gene, the expression of $\mathrm{p} 27^{\mathrm{kip} 1}$ protein by Western blotting was evaluated. As shown in Figure 3, upregulated of $p 27^{\text {Kip } 1}$ protein in pcDNA3.1-p27 ${ }^{\text {Kip } 1}$ wt-injected tumors was detected when compared with that in pcDNA3.1 empty vector-injected tumors. The expression of a-tubulin as an internal control was approximately the same in all of the tumors.

Proteolytic activities of caspase-3 and $\mathbf{- 9}$. The activity of caspase- 3 dan -9 in SP-C3-p27 $7^{\text {kip } 1}$ wt or SP-C3-neo was investigated. As seen in Figure 4, SP-C3-p27 ${ }^{\text {Kip } 1}$ wt showed increased caspase- 3 and 9 proteolytic activities as compared with that of SP-C3-neo. Proteolytic activities of caspase-3 in SP-C3-p27 ${ }^{\text {Kip } 1}$ wt was 2.9 fold increased compared with SP-C3-neo. Furthermore, proteolytic activities of caspase-9 in SP-C3-p27 ${ }^{\text {kip } 1}$ wt was 1.7 fold increased $(P=0.001)$.

\section{DISCUSSION}

Cell membranes electro-gene therapy has been developed for the purpose of achieving highly efficient in vitro gene and/or drug transfer. ${ }^{2}$ Interestingly, the application of electrogene therapy to cultured cells has been well established, but the use of in vivo electro-gene therapy has received little attention. ${ }^{9}$ In vivo electro-gene therapy has just recently been proposed for transdermal drug delivery ${ }^{5}$ and for electrochemotherapy with bleomycin of superficial tumors. ${ }^{6}$ Recently, successful in vivo transfer of IL genes into muscle, and transfer of marker and therapeutic suicide genes into normal tissues and tumors have been reported. ${ }^{26}$

In the present study, electro-gene therapy with naked plasmid DNA was evaluated. The wild type $\mathrm{p} 27^{\mathrm{Kip} 1}$ gene was used as a transfection gene and was evaluated its antitumor activity in human tongue base cancer (SP-C3 cell) xenograft. The results of study demonstrated the efficiency of 

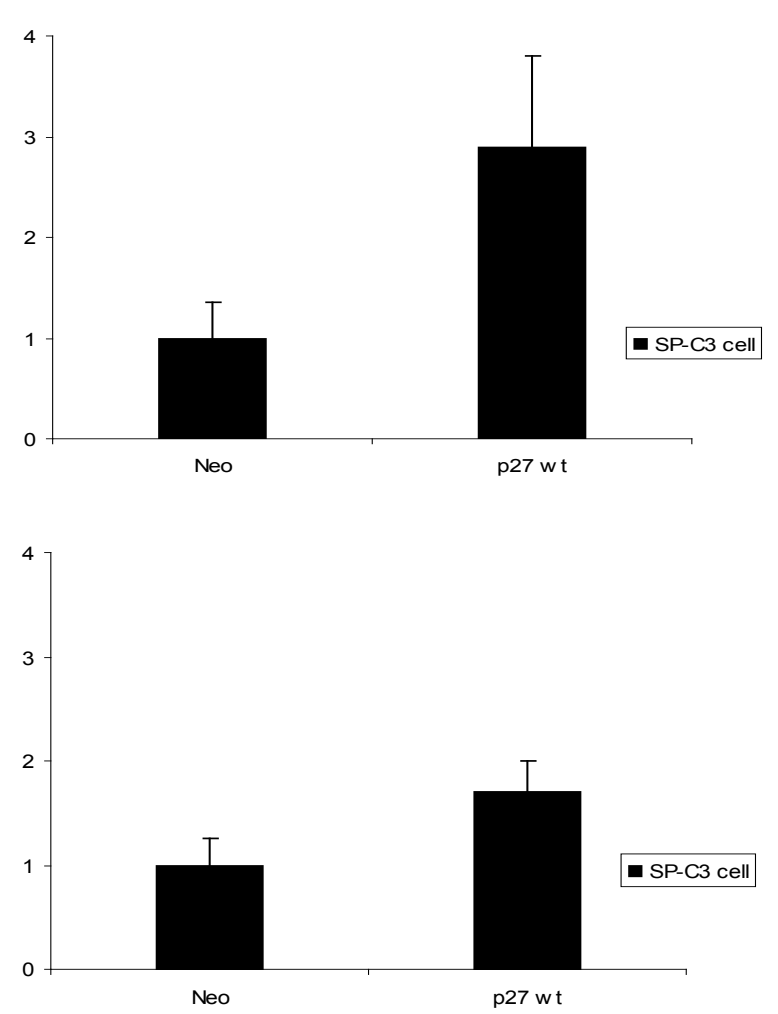

Figure 4. The activity of caspase- 3 and -9 in SP-C3 transfected cells.

electro-gene therapy was thought to be about $55-70 \%$ of cells, determined by EGFP expression as shown in Figure 1. Recently, the efficiency of electro-gene therapy followed by injection of pcDNA3.1-p27 $7^{\text {kip } 1}$ wt in human salivary gland cancer was about $45-65 \%$, and in a tongue cancer SP-C1 was about 53-75\%. Interestingly, the efficiency of electro-gene therapy followed by injection of 5 -fluorouracil in oral cancer was still lower than of non viral plasmid injection. ${ }^{29}$ Also, it was demonstrated that the transfection of wild type p27 $7^{\text {kip } 1}$ gene by electro-gene therapy could induce apoptotic cell death (Fig. 4), and inhibit the growth of SP-C3 cancer xenografts (Fig. 2). Furthermore, wild type p $27^{\text {kip } 1}$ gene by electro-gene therapy could induce the expression of p27 $7^{\text {Kip } 1}$ protein (Fig. 3 ), which has the negative regulator function in the cell cycle. Therefore, electro-transfer of plasmid DNA p27 ${ }^{\text {Kip } 1}$ wt into SPC3 xenograft can be successfully achieved using disk-shaped electrodes. Suggesting that clinical application using this electro-gene therapy system for oral cancer may be possible in the future.

On the other hands, some disadvantages of this method should be considered. Although transfection by electro-gene therapy inhibited the growth of SP-C3 cancer xenografts, the target area was limited to local tumors and the growth of multiple metastatic lesions cannot be target for efficient suppression. For that reason, with a view to obtaining more effective gene therapy using electroporation for head and neck cancer and oral cancer, writter plan to attempt gene transfer with several other genes and to use various anticancer agents in combination with gene transfection by this electro-gene therapy system.

In conclusion, in vivo electro-gene therapy following by intratumoral injection of pcDNA3.1p2 $7^{\text {Kip1 }}$ wt gene has a highly antitumor activity in human tongue base cancer xenografts. It might be possible to transfer pcDNA3.1-p27 ${ }^{\text {kip1 }}$ wt gene into human tongue base cancer xenograft. In vivo gene transfer method is a simple procedure and can solve some of the critical drawbacks of the present gene transfer techniques, thus providing a new strategy for gene therapy.

\section{ACKNOWLEDGMENTS}

I thank Prof. Mitsunobu Sato DDS., Ph.D, and Koji Harada, DDS., Ph.D, Department of Oral Maxillofacial Surgery and Oncology; Department of Therapeutic Regulation for Oral Tumor, Institute of Health Biosciences, School of Dentistry, Tokushima University, Japan, for their valuable advices and providing materials. Also, I thank Dr. J. Massague, Howard Hughes Medical Institute, Memorial SloanKettering Cancer Center, New York. Thanks to drg. Sartari E. Yuletnawati, our staff in Oral Medicine and co-asst FKG-UGM for finishing this research.

\section{REFERENCES}

1. Nishi T, Yoshizato K, Yamashiro S, Takeshima $\mathrm{H}$, Sato K, Hamada K, et al. High efficiency in vivo gene transfer using intra arterial plasmid DA injection following in vivo electroporation. Cancer Res 1996;56:1050-5.

2. Matthew KE, Dev SB, Toneguzzo F, Keating A. Electroporation for gene therapy. In: Nickoloff JA (editor). Methods in molecular biology. Vol. 48. Animal cell electroporation protocols. Totowa, NJ: Humana Press, Inc.; 1995. p. 27380.

3. Sukharev SI, Klenchin VA, Serov SM, Chernomordik LV, Chizmadzhev, Yu A. Electroporation 
and electroporetic DNA transfer into cells: The effect of DNA interaction with electropores. Biophys J 1992;63:1320-7.

4. Belehradek $M$, Domenge $C$, Luboinski B, Orlowski S, Belehradek J Jr, Mir LM. Electrochemotherapy, a new antitumor treatment. First clinical phase I-II trial. Cancer 1993;72:3694700.

5. Chu G, Hayakawa H, Berg P. Electroporation for the efficient expression of mammalian cells with DNA. Nucleic Acids Res 1987;15:1311-26.

6. Suzuki T, Shin BC, Fujikura K, Matsuzaki T, Takata K. Direct gene transfer into rat liver cells by in vivo electroporation. FEBS Lett 1998;425:436-40.

7. Anderson KP, Lingrel JB. Glucocorticoid and estrogen regulation of a rat T-kininogen gene. Nucleic Acids Res 1989;17:2835-48.

8. Keating A, Toneguzzo F. Gene transfer by electroporation: a model for gene therapy. Prog Clin Biol Res 1990;333:491-8.

9. Titomirov AV, Sukharev S, Kristanova E. In vivo electroporation and stable transformation of skin cells of new born mice by plasmid DNA. Biochem Biophys Acta 1991;1088:131-4.

10. Andreason GL, Evans GA. Optimization of electroporation for transfection of mammalian cells. Anal Biochem 1989;180:269-75.

11. Jiao S, Williams P, Berg RK, Hodgeman BA, Liu $L$, Repetto $G$. Direct gene transfer into non human primate myofibers in vivo. Hum Gene Ther 1992;3:21-33.

12. Ammar A, Uchida D, Begum NM, Tomizuka Y, Iga $\mathrm{H}$, Yoshida $\mathrm{H}$, Sato M. The clinicopathological significance of the expression of CXCR4 protein in oral squamous cell carcinoma. Int $\mathrm{J}$ Oncol 2004;25:65-71.

13. Supriatno, Harada K, Yoshida H, Sato M. Basic investigation on the development of molecular targeting therapy against cyclin-dependent kinase inhibitor $\mathrm{p} 27^{\mathrm{kip} 1}$ in head and neck cancer cells. Int J Oncol 2005;27(3): 627-35.

14. Inagi $\mathrm{K}$, Takahashi $\mathrm{H}$, Okamoto $\mathrm{M}$, Nakayama M, Makoshi T, Nagai $H$. Treatment effects in patients with squamous cell carcinoma of the oral cavity. Acta Otolaryngol Suppl 2002;547:25-9.

15. Parkin DM, Pisani P, Ferlay J. Estimates of the worldwide incidence of 25 major cancers in 1990. Int J Cancer 1999;80:827-41.
16. Sherr C, Roberts JM. Inhibitors of mammalian G1 cyclin-dependent kinases. Genes Dev 1995;9:1149-63.

17. Catzavelos C, Bhattacharya N, Ung YC, Wilson JA, Roncari L, Sandhu C. Decreased levels of the cell-cycle inhibitor p27 ${ }^{\text {kip } 1}$ protein: Prognostic implications in primary breast cancer. Nat Med 1997;3:227-30.

18. Porter PL, Malone KE, Heagerty PJ, Alexander GM, Gatti LA, Firpo EJ, et al. Expression of cell-cycle regulators $\mathrm{p} 27^{\mathrm{Kip} 1}$ and cyclin $\mathrm{E}$, alone and in combination, correlate with survival in young breast cancer patients. Nat Med 1997;3:222-5.

19. Harada K, Supriatno, Yoshida H, Sato M. Low p2 $7^{\text {Kip } 1}$ expression is associated with poor prognosis in oral squamous cell carcinoma. Anticancer Res 2002;22:2985-9.

20. Lloyd RV, Erickson LA, Jin L, Kulig E, Qian X, Cheville JC. p27 ${ }^{\text {Kip1 }}$ a multifunctional cyclindependent kinase inhibitor with prognostic significance in human cancer. $M \mathrm{~J}$ Pathol 1999;154:313-23.

21. Nakayama $K$, Ishida $N$, Shirane $M$, Inomata A, Inoue T, Shishido N. Mice lacking p2 $7^{\text {Kip1 }}$ display increased body size, multiple organ hyperplasia, retinal dysplasia and pituitary tumors. Cell 1996;85:707-20.

22. Supriatno, Harada K, Hoque MO, Bando T, Yoshida $\mathrm{H}$, Sato $M$. Overexpression of $\mathrm{p} 27^{\mathrm{kip} 1}$ induces growth arrest and apoptosis in an oral cancer cell lines. Oral Oncol 2002;38:730-6.

23. Supriatno, Harada K, Kawaguchi S, Yoshida $H$, Sato M. Effect of p27 $7^{\text {Kip } 1}$ on the ability of invasion and metastasis of an oral cancer cell line. Oncol Rep 2003;10:527-32.

24. Powel KT, Morgenthaler AW, Weaver JC. Tissue electroporation. Observation of reversible electrical breakdown in viable frog skin. Biophys J 1989;56:1163-71.

25. Mir LM, Banoun H, Paoletti C. Introduction of definite amounts of non permanent molecules into living cells after electropermeabilization: direct access to the cytosol. Exp Cell Res 1988;175:15-25.

26. Goto T, Nishi T, Tamura T, Dev SB, Takeshima H, Kochi M. Highly efficient electro-gene therapy of solid tumor by using an expression plasmid for the herpes simplex virus thymidine kinase gene. Proc Natl Acad Sci USA 2000;97:354-9. 